\title{
New record of Scaphyglottis livida (Lindl.) Schltr. (Orchidaceae, Epidendroideae) in Goiás, and a key to Scaphyglottis species in the Central-West Region of Brazil
}

\author{
Igor Soares dos Santos ${ }^{1}$, Marcos José da Silva²
}

1 Federal University of Goiás, Institute of Biological Sciences, Department of Botany, Laboratory of Morphology and Plant Taxonomy, Alameda Ingá, Quadra A, Campus Samambaia, Goiânia, GO, CEP 74001-970, Brazil. 2 Federal University of Goiás, Institute of Biological Sciences, Department of Botany, Laboratory of Molecular Systematics and Plant Taxonomy, Laboratory of Morphology and Plant Taxonomy, Alameda Ingá, Quadra A, Campus Samambaia, Goiânia, GO, CEP 74001-970, Brazil.

Corresponding author: Igor Soares dos Santos, igorsoares1237@gmail.com

\begin{abstract}
Botanical studies and exploration of Orchidaceae in Chapada dos Veadeiros National Park, Goiás state, Brazil, found a unreported species in the state. The presence of Scaphyglottis livida (Lindl.) Schltr. is reported, an illustration and distribution map are provided, and the morphological relationships of S. livida to other similar species, as well as its phenology, are discussed. A key to the species of the genus Scaphyglottis occurring in the Central-West Region of Brazil; images of these species are also provided.
\end{abstract}

Keywords

Cerrado, Chapada dos Veadeiros, geographic distribution, orchids, taxonomy.

Academic editor: Alexander Zizka | Received 15 August 2019 | Accepted 11 November 2019 | Published 10 January 2020

Citation: Santos IS, Silva MJ (2020) New record of Scaphyglottis livida (Lindl.) Schltr. (Orchidaceae, Epidendroideae) in Goiás, and a key to Scaphyglottis species in the Central-West Region of Brazil. Check List 16 (1): 9-15. https://doi.org/10.15560/16.1.9

\section{Introduction}

Scaphyglottis Poepp. \& Endl. comprises about 75 species distributed from Mexico to southern Brazil, with its center of diversity in the cloud forests of Costa Rica and Panama, where $70 \%$ of the species are found (Dressler 2001; Dressler et al. 2004; Pridgeon 2005; Archilla 2012; Archilla and Chiron 2013; Szlachetko and Kolanowska 2014). In Brazil, the genus is represented by 14 species distributed throughout all regions of the country (BFG 2015; Barros et al. 2015). Scaphyglottis belongs to the family Orchidaceae Juss., subfamily Epidendroideae Lindl., tribe Epidendreae Lindl., subtribe Laeliinae Benth. It includes plants with basal or overlapping pseudobulbs with 1-2 apical leaves, flowers in fascicles, racemes, or panicles; Flowers with similar sepals and petals. The petals are wider than the sepals. The lip of these plants is entire or 3-lobed and occasionally callous, the prominent column foot is fused to the lip and 4 or 6 yellow pollinia are produced (Dressler 2001; Dressler et al. 2004; Kolanowska 2013; Szlachetko and Kolanowska 2014). Species can be differentiated by pseudobulbs, leaves, and, above all, by the morphology of their flowers (petals, sepals, column, and the shape of the lip and its ornamentation).

During a taxonomic survey on the Orchidaceae of Chapada dos Veadeiros National Park, Goiás Brazil, we found S. livida (Lindl.) Schltr. growing as an epiphyte 


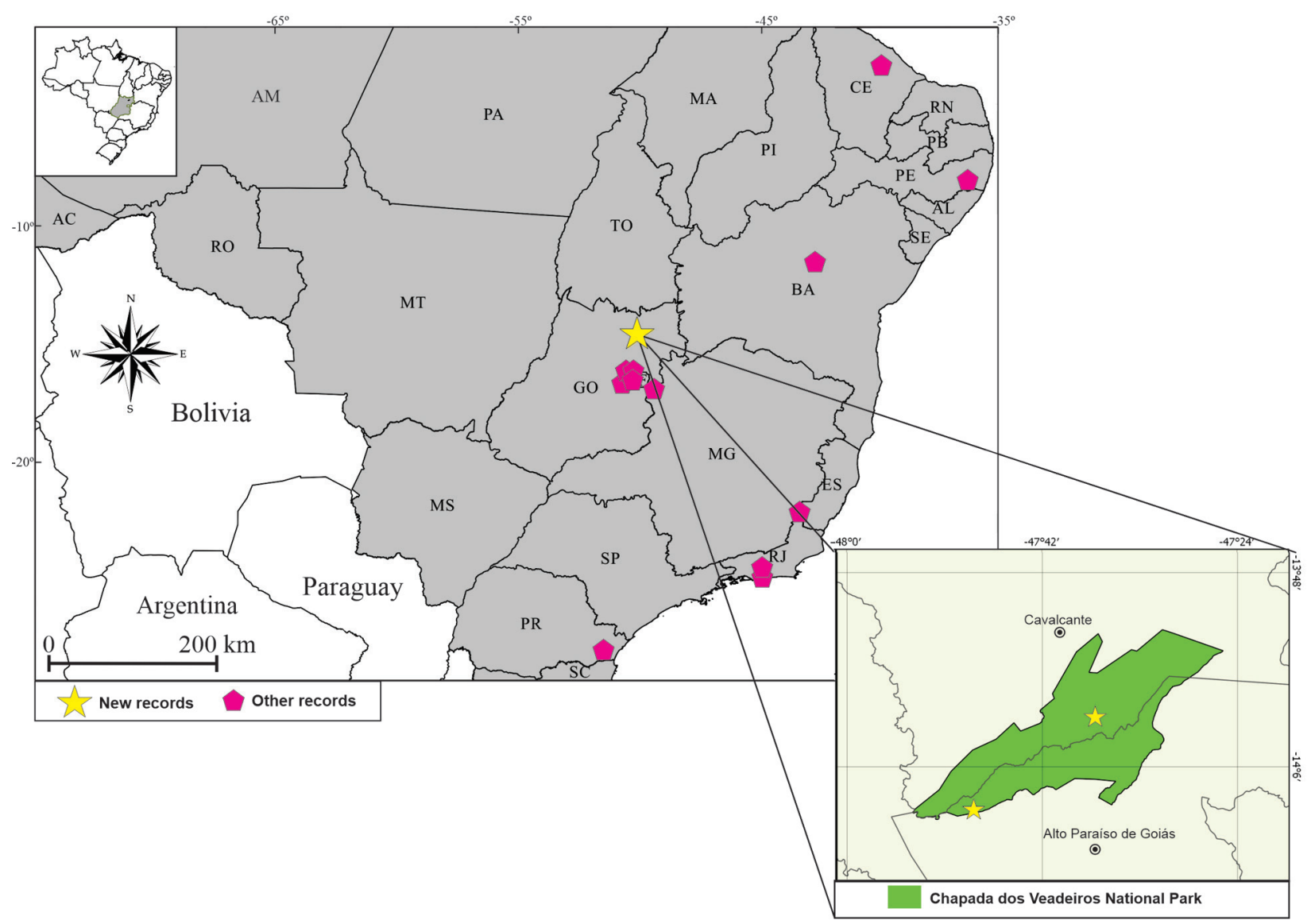

Figure 1. Geographic distribution of Scaphyglottis livida (Lindl.) Schltr. New records of S. livida in the Chapada dos Veadeiros National Park (Goiás). BA = Bahia. $\mathrm{CE}=$ Ceará. DF = Distrito Federal. ES = Espírito Santo. GO = Goiás. MT = Mato Grosso. MS = Mato Grosso do Sul. MG = Minas Gerais. $\mathrm{PE}=$ Pernambuco. $\mathrm{PR}=$ Paraná. $\mathrm{RJ}=$ Rio de Janeiro and $\mathrm{TO}=$ Tocantins.

in gallery forests or on rocks in Cerrado vegetation. The species represents the first record for the genus and specie in the state of Goiás.

\section{Methods}

Study site. Chapada dos Veadeiros National Park, one of the largest and most preserved protected areas of Brazil, is located in northeastern Goiás state (Fig. 1). The park has an area of 65,510 ha and was created for the conservation of a mountainous complex with various types of soils and reliefs. The altitude of the study area extends from 800 to $1.676 \mathrm{~m}$ a.s.l. The vegetation is diverse and includes rocky fields, Cerrado sensu stricto, gallery forests, Veredas, and seasonal dry forests. About 2,660 plant species are known in the Park. Many of these species are endemic and rare; little is known about the actual diversity of the flora and there are few local studies (Mittermeier et al. 2005; Mendonça et al. 2008; Lenza et al. 2011). Two defined seasons are observed in the area (one dry and one rainy), with annual average precipitation between 1,500 and 1,750 $\mathrm{mm}$ and temperatures between 24 and $26{ }^{\circ} \mathrm{C}$ (Felfili et al. 2007). The collection of botanical material was allowed by SISBIO/ IBAMA and by CNPq, proc. no. 445669/2014-4.

Scaphyglottis livida was identified based on the work of Archilla and Chiron (2013) and comparisons with specimens at CEN, EAC, HEPH, P, RB, S and UFG herbaria (acronyms following Thiers 2019). In this study, we made 20 monthly surveys between July 2017 and October 2018. The species' description and identification key is based on the morphological variation of all examined collections of BHCB, CEN, EAC, HEPH, INPA, K, MO, $\mathrm{P}, \mathrm{RB}, \mathrm{S}, \mathrm{UB}$, and UFG herbariums. The terminology follows Archilla and Chiron (2013). For the illustration of the species, samples were preserved in $70 \%$ alcohol and examined with a Leica stereomicroscope EZ4 coupled to a light camera. The distribution map was prepared using QGIS version 3.2.3 (QGIS Development Team 2018). The geographic coordinates of particular populations were obtained in the field or taken from labels of exsiccates. Vouchers of the collected materials were deposited at the Herbarium of the Federal University of Goiás (UFG).

\section{Results}

Scaphyglottis livida (Lindl.) Schltr., Beih. Bot. Centralbl. 36 (2): 457.1918.

Figures 2, 3

New records. Brazil: Goiás: Cavalcante, Chapada dos Veadeiros National Park, Sete Quedas of Rio Preto, $14^{\circ} 06^{\prime} 24^{\prime \prime}$ S, 04744'54"W, 25 Aug. 2017, fl., I.S. Santos 


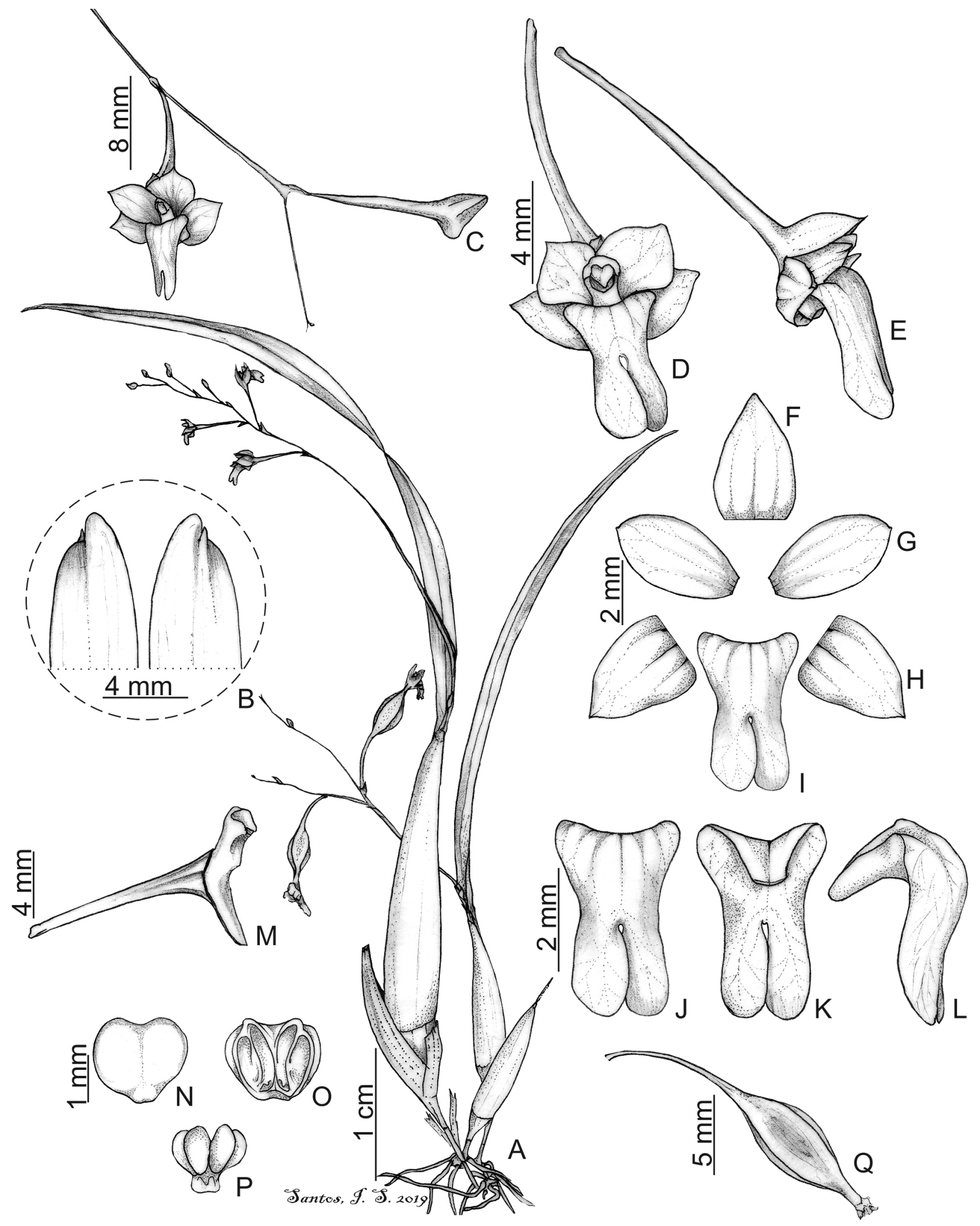

Figure 2. Scaphyglottis livida (Lindl.) Schltr. A. Habit. B. Leaf apex detail, upper and lower face. C. Racemose inflorescence. D. Flower, frontal view. E. Flower, lateral view. F. Dorsal sepal. G. Petal. H. Lateral sepal. I. Lip. J. Lip, adaxial view. K. Lip, abaxial view. L. Lip, lateral view. M. Column. N. Anther, dorsal view. O. Anther, ventral view. P. Pollinia. Q. Capsule (I.S. Santos et al. 473).

et al. 184 (UFG); ibid., 25 Aug. 2017, fl., I.S. Santos et al. 194 (UFG); ibid., ca 1.150 m, 25 May 2018, fl., fr., I.S. Santos et al. 473 (UFG); 25 Aug. 2017, fl., fr., M.J. Silva et al. 8875 (UFG); São Jorge, 18 Nov. 1999, fl., F. Chagas s.n. (HEPH 24457).
Identification. Epiphytic or rupicolous herbs, 5.8-9.5 $\mathrm{cm}$ tall. Rhizome 1-3 $\mathrm{mm}$ long between pseudobulbs, cylindrical, inconspicuous, non-superposed. Pseudobulbs $0.7-9.3 \times 0.2-1.3 \mathrm{~cm}$, fusiform, longitudinally sulcate, heteroblastic, greenish-purplish. Leaves $4.8-20 \times$ 

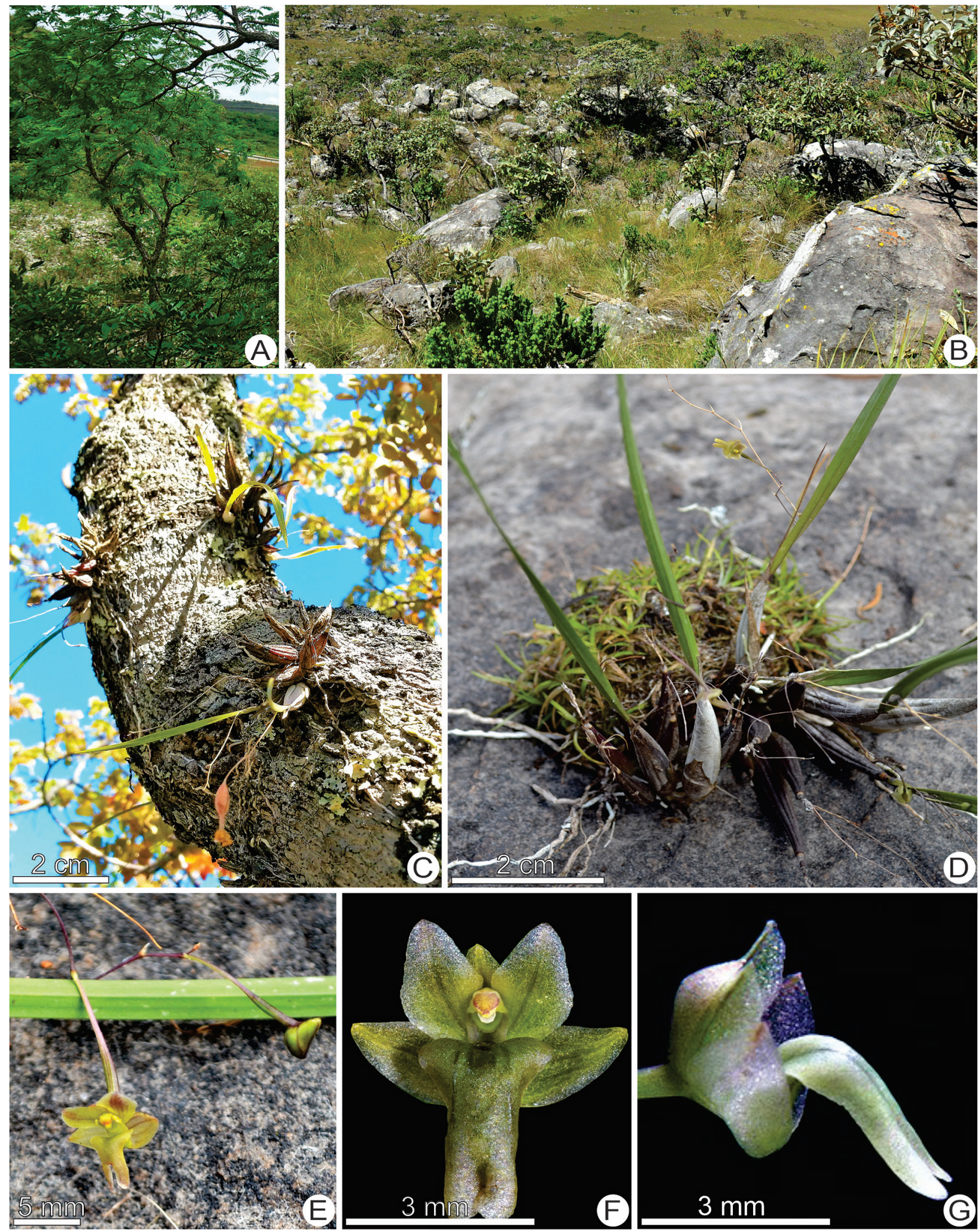

Figure 3. Scaphyglottis livida (Lindl.) Schltr. A, B. Habitats: (A) gallery forests; (B) Cerrado rupestre. C, D. Habit. E. Detail of the inflorescence. F. Flower, frontal view. G. Flower lateral view.

$0.3-0.5 \mathrm{~cm}$, flat, linear-lanceolate, subcoriaceous, green, apex asymmetric. Racemes, $1.7-8.5 \mathrm{~cm}$ long, pauciflorous, terminal, lax, pendulous; scape $1.3-5.3 \mathrm{~cm}$, rachis $0.6-7.5 \mathrm{~cm}$ with $1-7$ flowers. Bracts membranaceous, apex acute; bracts those of the floral scape, 12-28 $\times 2-6 \mathrm{~mm}$, ovate; floral bracts $1-7 \times 1-6 \mathrm{~mm}$ triangulate. Flowers, resupinate, glabrous, light green. Ovary pedicellate, $8-17 \mathrm{~mm}$ long, purple-green. Sepals and petals membranous green-white. Dorsal sepal 2-4 × 2-2.6 $\mathrm{mm}$, ovate, apex obtuse. Lateral sepals $3-4 \times 2-3 \mathrm{~mm}$, oval, apex obtuse and shortly mucronate. Petals 3-4 $\times$ 2-2.6 mm, elliptic or elliptic-obovate membranous, green-white, rounded apex. Lip 5.5-7 × 3-6 mm, panduriform, light green, slightly purplish, apex 2-lobed, 
lobes rounded. Column 1-2 mm long, not winged but with inconspicuous lateral teeth, green-white. Anthers 1 $\times 1 \mathrm{~mm}$, broadly oval, yellow-white, apex rounded; pollinia four, yellow. Capsules $1.4-2.3 \times 0.3-0.5 \mathrm{~cm}$, ellipsoid, 6- ribbed, pendulous.

Of the species that occur in Brazil, S. livida is morphologically most similar to $S$. fusiformis (Griseb.) R.E. Schult. due to its fusiform pseudobulbs, usually unifoliate growth form, and flowers in racemes with sepals and petals light green. However, S. livida differs from this species in having the lip without callus (vs with humplike callus at base in S. fusiformis), sepals and petals with green stripes (vs purple stripes), lip 2-lobed, the lobes rounded (vs 3-lobed, the lobes truncate), petals with 3-4 $\mathrm{mm}$ long, elliptic or elliptic-obovate (vs 4-7.8 mm long, oblong-elliptic to oblanceolate), and inflorescence racemose (vs fasciculate, 1-flowered or shortly racemose).

Because the taxonomic knowledge on the genus Scaphyglottis in the Central-West Region of Brazil is scarce and collections of the genus in the local herbaria (HEPH, UB, UFG) are often not identified to species or are frequently misidentified, we provide an identification key and photographs (Fig. 4A-F) of Scaphyglottis species occurring in this region .

\section{Key to Scaphyglottis species occurring in the Central-West Region of Brazil}

1. Plants with flowers arranged in racemes; solitary pseudobulbs with a single terminal leaf(Figs 2, 3, 4B) ........ S. livida (Lindl.) Schltr.

1'. Plants with solitary flowers or arranged in fascicles; pseudobulbs aggregated with two terminal leaves .......

2. Linear leaves; petals ca $4-5 \mathrm{~mm}$ in length, apex acute

3. Greenish-white flowers; basal portion of lip wider than distal one; greenish-white column with irregular and inconspicuous wings (Fig. 4A) .................. S. boliviensis (Rolfe) B.R.Adams

3'. Pink flowers; basal portion of lip narrower than distal; magenta column with triangular and conspicuous wings (Fig. 4F)

S. stellata Lodd. ex Lindl.

2'. Elliptical and lanceolate leaves; petals ca 2-3 mm in length, apex obtuse or rounded ............................ 4

4. Cream sepals and petals; lip unlobed, spatulatebroad, apex emarginate (Fig. 4D)

S. prolifera (R.Br.) Cogn.

4'. Greenish or yellowish-white sepals and petals; lip 3-lobed, obovate, apex acute ......................... 5

5. Lanceolate leaves, apex acute; yellow flowers; winged column, vinaceous-yellow; vinaceous anthers (Fig. 4C)

S. modesta (Rchb.f.) Schltr.

5'. Elliptic leaves, apex emarginate; white flowers; wingless column, green; yellow anthers (Fig. 4E) S. sickie Pabst

\section{Discussion}

Scaphyglottis livida occurs in Belize (Adams and Cribb 1985), Colombia, Ecuador, Guatemala (Archilla and Chiron 2013), Honduras, Mexico, Peru, and Venezuela (Govaerts et al. 2011). According to Barros (2015), BFG (2015), Carmo and Kamino (2017), and Barros et al. (2018), this species occurs in the Central-West (Distrito Federal, Mato Grosso do Sul), Southeast (Espírito Santo, Minas Gerais, Rio de Janeiro), Northeast (Bahia, Ceará, Pernambuco), and South (Paraná) regions of Brazil (Fig. 1). This study represents the first account of this species for the Goiás state (Fig. 1). In the study area S. livida was found growing as an epiphytic in gallery forests or on rocks in Cerrado vegetation. The population included 6 and 16 individuals, found with flowers and fruits between August and November, being rarely found with flowers and fruits between November and May, growing at altitudes between 1,000-1,147 m elevation. The present work is an update on the geographic distribution of $S$. livida and contributes to the knowledge about the genus in the Central-West Region of Brazil, particularly in the state of Goiás. In Goiás, three species are now known: $S$. livida (Lindl.) Schltr., S. modesta (Rchb. F.) Schltr., and S. prolifera (Sw.) Cogn.

\section{Acknowledgements}

We thank the Federal University of Goiás, for the availability of transport and facilities; Sistema de Autorização e Informação da Biodiversidade/Instituto Brasileiro do Meio Ambiente e dos Recursos naturais Renováveis (SISBIO/IBAMA) for permission to carry out fieldwork in the Chapada dos Veadeiros National Park; Conselho Nacional de Desenvolvimento Científico e Tecnológico $(\mathrm{CNPq})$ for granting the productivity scholarship to Marcos José da Silva, the grant of Scientific Initiation to Igor Soares dos Santos, and for the financial support for the Project "Levantamento Florístico do Parque Nacional da Chapada dos Veadeiros, Goiás, Brasil" (proc. no. 445669/2014-4). We thank Marta Kolanowska and Felipe Bittencourt for their comments which considerably improved the manuscript.

\section{Authors' Contributions}

ISS and MJS wrote the manuscript, and collected, identified, and photographed the specimens. ISS made the distribution map and figures of species.

\section{References}

Adams BR, Cribb PJ (1985) A new species and new records of Orchidaceae for Belize. Kew Bulletin 40 (3): 637642. https://doi.org/ $10.2307 / 4109624$

Archilla F (2012) Nuevas especies Guatemaltecas honrando a grandes botánicos. Revista Guatemal. 15 (1): 97-114.

Archilla F, Chiron G (2013) Mise à Jour de la liste de Scaphyglottis 


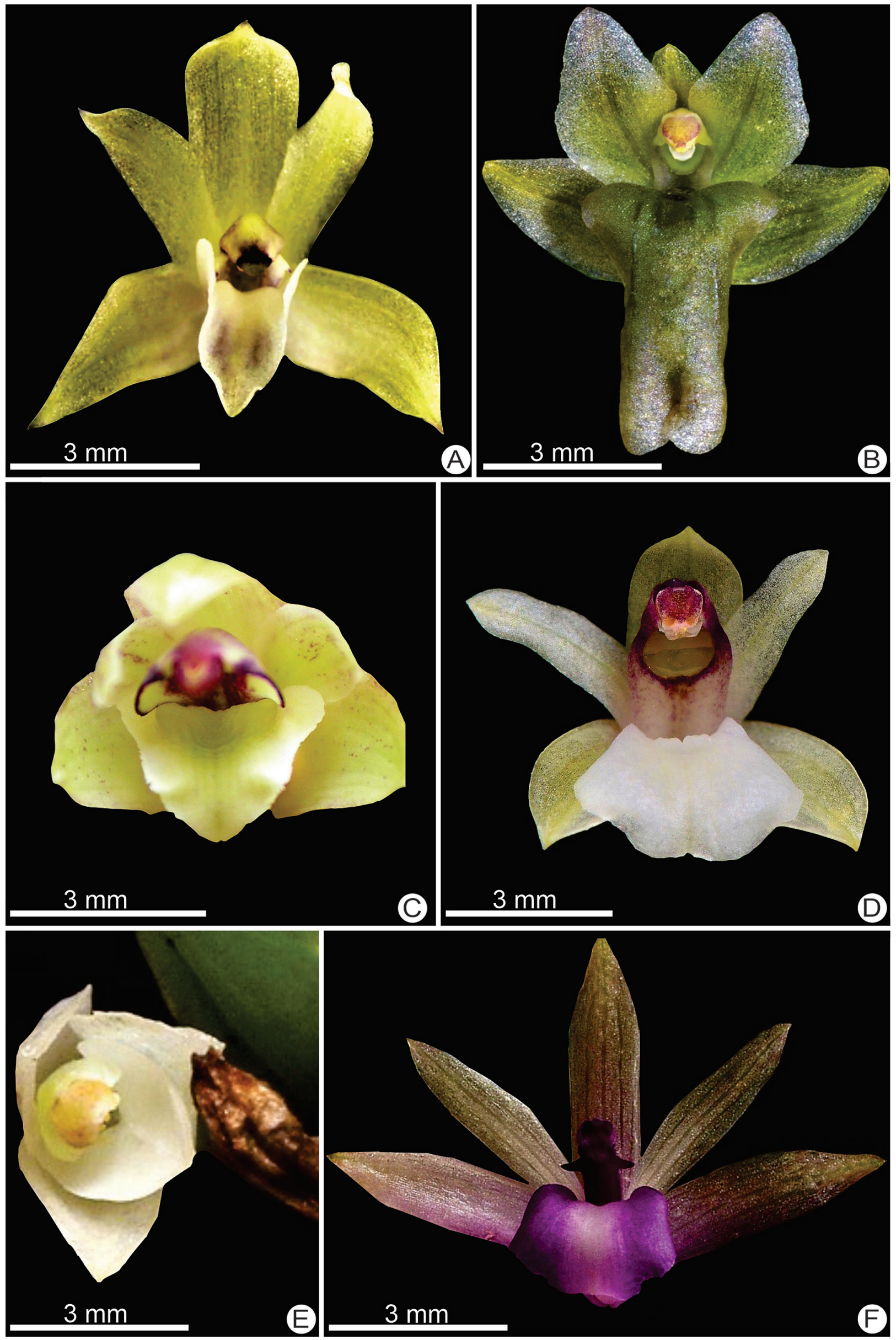

Figure 4. Scaphyglottis Poepp. \& Endl. species occurring the Central-west region of Brazil. A. S. boliviensis (Rolfe) B.R. Adams. B. S. livida (Lindl.) Schltr. C. S. modesta (Rchb. f.) Schltr. D. S. prolifera (Sw.) Cogn. E. S. sickii Pabst. F. S. stellata Lodd. ex Lindl. 
(Orchidaceae, Laeliinae) au Guatemala, avec une nouvelle espèce. Richardiana 13: 177-183.

BFG (The Brazil Flora Group) (2015) Growing knowledge: an overview of seed plant diversity in Brazil. Rodriguésia 66 (4): 1085 1113. https://doi.org/10.1590/2175-7860201566411

Barros F, Vinhos F, Rodrigues VT, Barberena FFVA, Fraga CN, Pessoa EM, Forster W, Neto ML, Furtado SG, Nardy C, Azevedo CO, Guimarães LRS (2015) Orchidaceae. In: Lista de espécies da flora do Brasil. Jardim Botânico do Rio de Janeiro. Disponivel em: http://floradobrasil.jbrj.gov.br/jabot/floradobrasil/FB12207. BFG Growing knowledge: an overview of Seed Plant diversity in Brazil. Rodriguésia 66 (4): 1085-1113. https://doi.org/10.1590/21757860201566411

Carmo FF, Kamino LHY (2017) O Vale do rio Peixe Bravo: ilhas de ferro no sertão mineiro. 3i Editora, Belo Horizonte, 207 pp.

Dressler RL (2001) Scaphyglottis. In: Pridgeon AM, Cribb PJ, Chase MW, Rasmussen FN (Eds) Genera Orchidacearum. Vol. 4. Epidendroideae (Part 1). Oxford University Press, Oxford, 310-313.

Dressler RL, Whitten M, Williams NH (2004) Phylogenetic relationships of Scaphyglottis and related genera (Laeliinae: Orchidaceae) based on nrDNA ITS sequence data. Brittonia 56: 58-66. https://doi.org/10.1663/0007-196x(2004)056[0058:prosar]2.0.co;2

Felfili JM, Rezende AV, Silva Júnior MC (2007) Análise florística da Chapada dos Veadeiros. Biogeografia do bioma Cerrado: vegetação e solos da Chapada dos Veadeiros. Editora da Universidade de Brasília, Finatec, Brasília, 256 pp.

Govaerts R, Dransfield J, Zona SF, Hodel DR, Henderson A (2011) World checklist of Orchidaceae. http://apps.kew.org/wcsp. Accessed on: 2019-2-15.

Kolanowska M (2013) A new species of Scaphyglottis (Orchidaceae) from the Darién Gap, Colombia. Journal of the Torrey Botanical Society 140: 225-229. https://doi.org/10.3159/torrey-d-12-00066.1

Lenza E, Pinto JRR, Pinto AS, Maracahipes L and Bruziguessi EP (2011) Comparação da vegetação arbustivo-arbórea de umaárea de cerrado rupestre na Chapada dos Veadeiros, Goiás, e áreas de cerrado sentido restrito do Bioma Cerrado. Revista Brasileira de Botânica 34 (3): 247-259. https://doi.org/10.1590/S010084042011000300002

Mendonça RC, Felfili JM, Walter BMT, Silva-Júnior MC, Rezende AV, Filgueiras TS, Nogueira PE and Fagg CW (2008) Flora vascular do cerrado: Chech list com 12.356 espécies. In: Sano SM, Almeida SP, Ribeiro JF (Eds) Cerrado: ecologia e flora. Embrapa-CPAC, Planaltina, 417-1279.

Mittermeier RA, Robles Gil P, Hoffmann M, Pilgrim J, Brooks T, Mittermeier CG, Lamoreux J, Da Fonseca GAB (Eds). (2004) Pontos críticos revisitados: ecorregiões terrestres biologicamente mais ricas e ameaçadas de extinção da Terra. CEMEX/Agrupación Sierra Madre, Cidade do México. 392p.

Pridgeon AM, Cribb PJ, Chase MW, Rasmussen FN (2005) Genera Orchidacearum. Vol. 4. Epidendroideae (Part I). Oxford University Press, Oxford, 696 pp.

QGIS Development Team (2018) QGIS, version 3.2.3. Open Source Geospatial Foundation Project.

Szlachetko DL, Kolanowska M (2014) Two new species of Scaphyglottis (Orchidaceae, Epidendroideae) from Colombia. Polish Botanical Journal 59 (1): 1-5. https://doi.org/10.2478/pbj-2014-0011

Thiers B (2019) Index Herbariorum: a global directory of public herbaria and associated staff. New York Botanical Garden's Virtual Herbarium. http://sweetgum.nybg.org/science/ih/. Accessed on: 2019-2-15. 